\title{
Genetic diagnosis of root nodules bacteria isolated from some leguminous Plants in Nineveh Governorate
}

\author{
Samar Mahmood Alhayali ${ }^{1}$, Mohammed A. Al-Shakarchi ${ }^{2 *}$ \\ ${ }^{1}$ Department of Technical medical levorotary/Technical institute of Mosul/North Technical University/Iraq \\ ${ }^{2}$ Department of Biology/Education of Pure Science/University of Mosul/Iraq \\ Email: ${ }^{1}$ samar.esp51@uomosul.edu.iq,${ }^{2 *}$ dr.mohammedshz@uomosul.edu.iq
}

(Received August 31, 2021; Accepted November 03, 2021; Available online December 01, 2021)

DOI: 10.33899/edusj.2021.131302.1188, @ 2021, College of Education for Pure Science, University of Mosul.

This is an open access article under the CC BY 4.0 license (http://creativecommons.org/licenses/by/4.0/)

\begin{abstract}
Because of the importance of atmospheric nitrogen-fixing bacteria, the study aimed to isolate bacteria from the root nodules of plants from four areas within the city of Mosul during the winter planting period, for the season 2020-2021. Biochemical tests, phenotypic and agricultural characteristics were used to diagnose bacterial isolates and study their sensitivity and resistance to ten types of antibiotics. The results showed that the highest percentage of resistance was to the antibiotics Trimethoprim and Streptomycin at $100 \%$, while it was the least resistant to the antibiotics Tetracycline and Rifampicin at $22.2 \%$. The four bacterial isolates were resistant to cadmium chloride salts $(\mathrm{CdCl})$, while the lowest growth rate was when treated with mercury chloride salt $(\mathrm{HgCl})$. Polymerase Chain Reaction (PCR) technology was used to diagnose samples based on the analysis of nitrogenous bases in the 16S rRNA gene and compare the sequences generated by DNA amplification with standard isolates within NCBI to detect new isolated bacterial isolates.
\end{abstract}

Keyword: Rhizobium, Antibiotics, Heavy metals, PCR, 16S rRNA

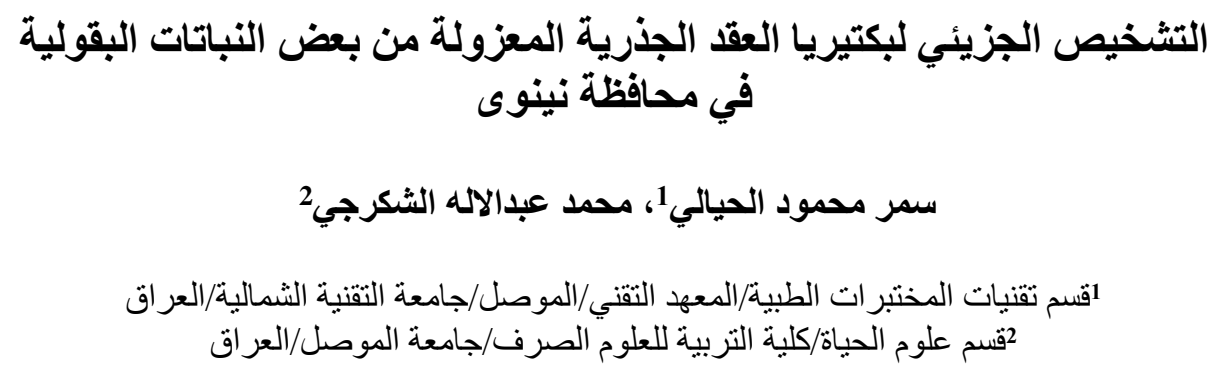

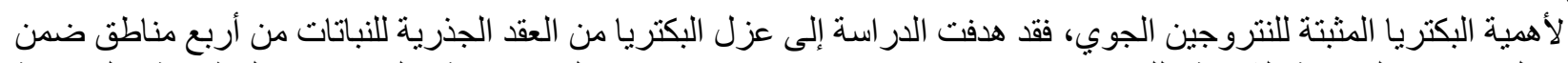

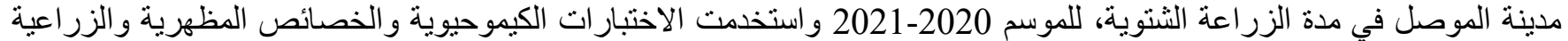

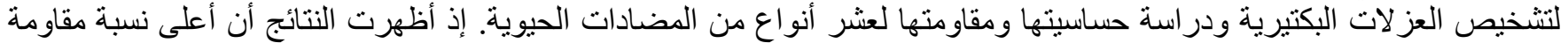

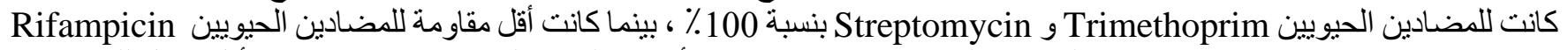
و Tetracycline بنسبة 22.2\%. وكانت العز لات البكتيرية الاربعة مقاومة لأملاح كلوريد الكادميوم (CdCl) بينما أقل معدل للنمو كانت 


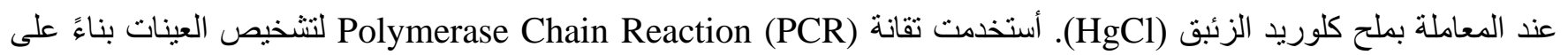

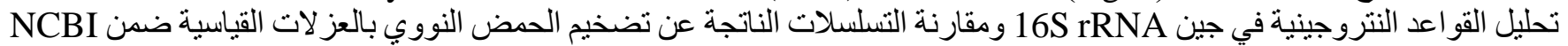
للكثف عن العزلات البكتيرية المعزولة الجديدة.

الكلمات المفتاحية : PCR ،16S rRNA المعادن الثقبلة، المضادات الحيوية، Rhizobium،

\section{Introduction}

The leguminous family Leguminosae is known as the Bean family, and It is a major source for humans and animals. It comes after cereal crops in terms of nutritional quality. It is a source of protein and calcium. There are 34 genera and 300 species in Iraq, in addition to 76 species grown for agricultural purposes. The legume family is considered one of the largest families of flowering plants (Angiosperms) [1]. Placed in Order Laguminalse, under three families fall: Pcaescaeae, (Papilionaceae) [2]. The members of this family are distinguished from other plant families by forming a symbiotic relationship with Rhizobia, where this relationship resulted in the formation of root nodules and the fixation of atmospheric nitrogen and its conversion into ammonia that can be utilized by plants [3]. The genera of the family Rhizobiaceae are Rhizobium and Allorhizobium and Mesorhizobuim and Bradyrhizobium and Sinorhizobium [4]. Members of this family are organotrophic, aerobic and facultative [5], is rod-shaped, don't from of spores, endemic to the soil and its members form root nodules that fix atmospheric nitrogen in the roots of legumes [6]. There are found in single or pairs and are motile by grow better growth ranges between $\left(25-30^{\circ} \mathrm{C}\right)$ and many of they are unable $\left(37^{\circ} \mathrm{C}\right)$ and they have the ability to benefit from a wide range of carbon compounds [7]. These bacteria are collected inside the ganglia to form the so-called Bacteroids, which have the ability to fix nitrogen [8]. The benefit of this symbiotic relationship is to improve the productivity of the soil in addition to its economic importance, in addition to the fact that the biological fixation of nitrogen pollutes the environment[9]. Local studies have shown the possibility of isolating different species of rhizobia from different areas of Nineveh Governorate [10][11]. More accurate and faster efficient molecular techniques have been developed to assist traditional phenotypic and morphological techniques in differentiating between different microbial genera, species and strains [12]. PCR primers for rhizobia species based on 16s rRNA sequence analysis and comparison with fixed data by DNA detection of species and shapes between strains of the same species using PCR technique to know and estimate the diversity of rhizobia and show ERIC and REP sequences are present in Rhizobia [13].The aims study to isolate the bacterial species belong to the genus Rhizobium from some leguminous plants in the some areas of Nineveh Governorate and to identify the isolated bacterial species using the microbiological, biochemica characteristics and their diagnosis at by using the specific PCR technique.

\section{Research Method}

\section{Isolation of Rhizobia bacteria from the root nodules of leguminous plants}

The nodules were separated and washed with distilled water. These nodules were immersed in ethanol (70\%) for 2-4 minutes and then washed several times with sterile distilled water, then the root nodules was immersed in a $3 \% \mathrm{NaOCl}$ solution 15 minutes [14], were washed with distilled water 3 times and placed on sterile filter papers to dry and to ensure the efficiency of marking the isolated root nodules were used [15]. Bacteria were cultured on Solid YEMA medium [16].

\section{Identification of bacteria (Rhizobium):}

The phenotypic characteristics were studied using Gram stain Kit using a compound light microscope $(100 \mathrm{X})[15]$. The isolated bacteria were classified according to their plant host into nine cases, and each culture was coded according to the Leguminous plant as in the following ( Table-1). 
Journal of Education and Science (ISSN 1812-125X), Vol: 30, No: 5, 2021 (163-177)

Table (1) The code of groups isolated bacteria were classified according to their plant host

\begin{tabular}{ccccccccc}
\hline $\begin{array}{c}\text { Vigna sp. } \\
\text { (Bean }\end{array}$ & $\begin{array}{c}\text { Pisum } \\
\text { sativum } \\
\text { (Pea) }\end{array}$ & $\begin{array}{c}\text { Phaseolus } \\
\text { vulgaris } \\
\text { (Common } \\
\text { bean) }\end{array}$ & $\begin{array}{c}\text { Lens } \\
\text { sp. } \\
\text { (Lentil) }\end{array}$ & $\begin{array}{c}\text { Cicer } \\
\text { arietinum } \\
\text { (Chickpea) }\end{array}$ & $\begin{array}{c}\text { Trigonella } \\
\text { foenum- } \\
\text { graecum } \\
\text { (Fenugreek) }\end{array}$ & $\begin{array}{c}\text { Vigna } \\
\text { unguiculata } \\
\text { (Cowpea) }\end{array}$ & $\begin{array}{c}\text { Trifolium } \\
\text { spp } \\
\text { (Clover) }\end{array}$ & $\begin{array}{c}\text { Medicago } \\
\text { sativa } \\
\text { (Alfalfa) }\end{array}$ \\
\hline $\mathrm{RhV}$ & $\mathrm{RhP}$ & $\mathrm{RhPh}$ & $\mathrm{RhC}$ & $\mathrm{RhA}$ & $\mathrm{RhG}$ & $\mathrm{RhR}$ & $\mathrm{RhM}$ & $\mathrm{RhS}$ \\
\hline
\end{tabular}

The family specialization test was conducted for the bacteria isolates under a study by taking of pure colony for each isolates to prepare $10 \mathrm{ml}$ of liquid YEM medium and placed for 48 hours in the shaking incubator with 150 cycles/ minute at $28^{\circ} \mathrm{C} \pm 1$ for 48 hours. The plant seeds were planted on NF medium after sterilization It was washed several times with running water and immersed in ethanol $70 \%$ concentrate for 2 minutes, then washed sterile distilled water for 3 times and then placed in $3 \%$ sodium hypochlorite solution $(\mathrm{NaOCl})$ for 15 minutes and then washed with sterile distilled water for 3 times and dried on several times., then the root total of plants inoculated after four to six days of growth using the inoculum $\left(10^{8} \times 3\right)$ cells $/ \mathrm{ml}$ the seedlings of the plants under study mentioned in table [1] was soaked with bacterial inoculum for 15 minutes and one method was used for surface sterilization of the seedlings mentioned above .To prepare the bacterial cutler for 4 days, according to the method of [17], and growing on a medium free of nitrogen (NF). The purpose of this is to ascertain the purity of the bacterial isolate and to make sure its ability to form root nodules on its host [18].

\section{The Heavy metals medium:}

Salts of heavy metals (mercury chloride, copper chloride, cadmium chloride, nickel chloride) to the sterilized YEMA media and cooled to a temperature $45-50^{\circ} \mathrm{C}$, each separately according to the method [19].

\section{The medium for selecting antibiotics:}

The appropriate antibiotic was added to the sterilized and cooled YEMA medium at a temperature of $45-50^{\circ} \mathrm{C}$ with final concentrations of micrograms per liter mentioned in Table -2 . The stock solutions of antibiotics were prepared according to the methods [20] [21].

Table 2- Stock and Final Concentrations of Antibiotics Solvent

\begin{tabular}{l|cccl}
\hline \multicolumn{1}{c|}{ Antibiotic } & Code & $\begin{array}{c}\text { Stockpile conc. } \\
(\mu \mathrm{g} / \mathrm{ml})\end{array}$ & $\begin{array}{c}\text { Final conc. } \\
(\mu \mathrm{g} / \mathrm{ml})\end{array}$ & \multicolumn{1}{c}{ Solvent } \\
\hline Tetracycline & Tet & 5 & 10 & Ethanol 70\% \\
Ampicillin & Amp & 5 & 50 & Sterile distilled water \\
Amoxicillin & Amo & 5 & 50 & Ethanol 70\% \\
Streptomycin & Str & 50 & 20 & Sterile distilled water \\
Rifampicin & Rif & 5 & 50 & Methanol \\
Nystatin & Nst & 5 & 50 & Ethanol 70\% \\
Erythromycin & Ery & 10 & 15 & Absolute ethanol \\
Gentamycin & Gen & 40 & 25 & Sterile distilled water \\
Trimethoprim & Tri & 5 & 50 & Ethanol 70\% \\
Cefixime & Cef & 5 & 50 & Sterile distilled water \\
\hline
\end{tabular}




\section{Biochemical tests for Rhizobium Bacterial Isolates:}

Some biochemical tests were used on the genera of Rhizobia isolated from the root nodules of the group of leguminous plant under study. The Citrate Utilization test was conducted according to the by a method of [22]. The urease product test was prepared according to the method [23], and the fluorescence test was performed according to the method [17]. The catalase test was conducted according to [24]. A gelatin liquefied test was carried out [17]. The Cytochrome Oxidase Test was performed by the method [23]. The Voges-Proskuar Test was prepared according to the method [25]. The Methyl Red Test was prepared according to the method [26]. Motility test was carried out according to the method [27]. The Indol Production Test was performed according to the method [28].Test (Bromothymol Blue Test BTB), The test was conducted according to the method [29]. The Macconkey Agar Medium test was prepared according to the method [30].

\section{Isolatio and purification of the genomic DNA cotent from Rhizobium}

Purification DNA Kit supplied by (Geneaid) was used to extract DNA from bacteria samples of the genus Rhizobium, by transferring pre-purified colonies of the root ganglion bacteria under study grown on YEMB liquid medium in a volume of $10 \mathrm{ml}$ and incubated in a Shaking Incubator at $(150 \mathrm{rpm})$ at a temperature of $28 \pm 1^{\circ} \mathrm{C}$ for $48-72$ hours and according to its protocolTo detect the purified DNA, the samples were transferred to a $1 \%$ agarose gel in Run Tank with a transducer using (X1) TBE buffer, and then the gel was imaged by Gel Documentation to be able to view the genomic DNA bundles as well as the PCR reaction product [31].

\section{Spcific Amplification of DNA-PCR:}

The purity and concentration of the DNA samples of the bacterial isolates understudy were measured by using Nanodrop to obtain the concentration required to perform the PCR reactions and it was (50) $\mathrm{ng} /$ microliter for each sample. Prepare the master reaction mixture for each PCR reaction by mixing the DNA sample and the special primer shown in Table (3) for each gene with the components of the mastermix inside a $0.2 \mathrm{ml}$ Eppendorf tube supplied by the English company Biolabs and complete the reaction volume to $20 \mu \mathrm{l}$ with distilled water, and then The mixture was discarded in the Microfuge for a period between (5-3) seconds to ensure that the reaction components did not remain on the walls of the reaction tubes. The reaction tubes were inserted into the Thermocycler to conduct the multiplication reaction using the special program for each reaction shown in Table (4):

\section{Table (3) Special primers used in the PCR reaction}

\begin{tabular}{c|c|c} 
Primer & Name & Sequence \\
\hline Forward & $\mathrm{pA}^{*}$ & AGAGTTTGATCCTGGCTCAG \\
Revers & $\mathrm{pH}^{*}$ & AAGGAGGTGATCCAGCCGCA
\end{tabular}

Table (4) The cycle of PCR program

\begin{tabular}{c|l|c|c|c} 
No. & \multicolumn{1}{|c|}{ Stage } & Temp. & Time (min.) & Cycle \\
\hline $\mathbf{1}$ & First Denaturation & 95 & 6 & 1 \\
$\mathbf{2}$ & Denaturation & 95 & 0.45 & \\
$\mathbf{3}$ & Annealing & 55 & 1 & 35 \\
$\mathbf{4}$ & Extension & 72 & 1 & \\
$\mathbf{5}$ & Final extension & 72 & 5 & 1
\end{tabular}




\section{Detection of nucleotide sequences for amplified DNA segments using DNA sequencing:}

Determining the sequence of nitrogenous bases to the bacterial samples understudy, as the PCR products of the 16SrRNA region were sent to the products of samples with the primers of the resulting. The sequence was read for the genes based on the 3130 Genetic Analyzer device supplied by the Japanese company Hitachi, and use the National Center Biotechnology (NCBI) and results were analyzed using Mole-Balast and Blast software.

\section{Results And Discussion}

\section{Diagnostic test for Rhizobia bacteria isolated:}

After 8 to 10 days the plant roots were periodically examined under a compound light microscope, and it was noticed that there was a deformation in the root hairs of leguminous root plants Figure -1). The researcher Selami and others were described through their study of the shape of the nodules and their anatomy in the plant Retama monosperma the country of Algeria that the shapes of the nodules are elongated[32].

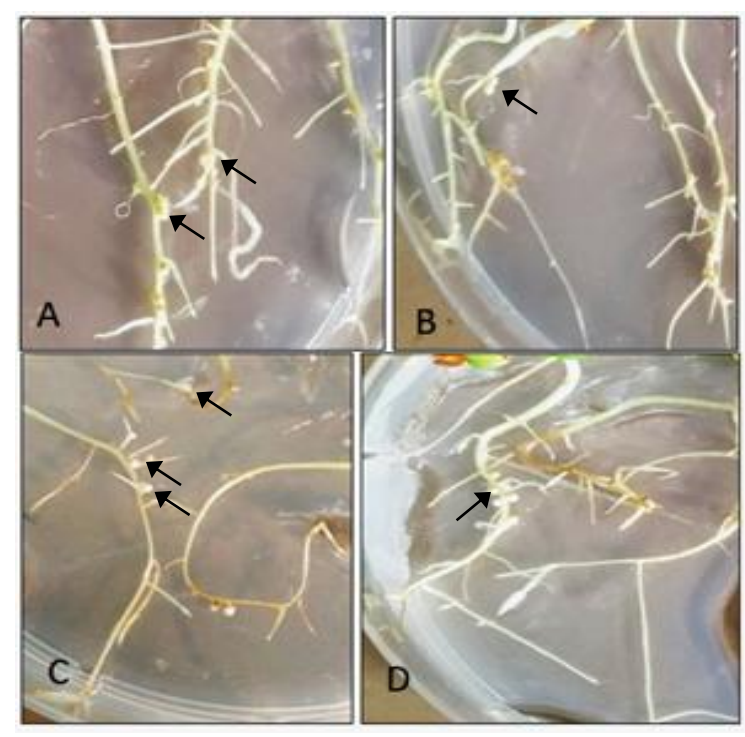

Figure 1-shows the root nodules and their shapes on the roots of some plants understudy

A: The root nodules formed on the roots of a Pea plant (indicator Part)

B: The root nodules formed on the roots of a bean plant (indicator Part)

C: The root nodules formed on the roots of a chickpea plant (indicator Part)

D: The root nodules formed on the roots of a ring plant (indicator Part)

\section{Morphological and Cultural Characters for Isolated Rhizobial Bacteria}

When bacterial colonies were grown in YEMA medium, they appear of different colors between ivory and cream, circular and sticky, with smooth edges. It was observed that these bacterial colonies produce in rich media on this technology with carbon exopolysaccharides, and after several days of their growth in YEMA medium, the colonies sticky substance on the cover of the dish even if it is stored at a temperature of $4^{\circ} \mathrm{C}$. A single colony was taken from the culture and stained by the gram, then they were examined by a compound light microscope (100X), they appear gram-negative, this was noted by the researchers [1].

\section{Biochemical Tests:}

Table -5A-B of biochemical tests were shown the results, where all the isolates understudy were positive for the motility test, and these results were almost identical to the results of [33]. As for the 
production test, all samples under study and all sugars were positive, and the results were similar to those of [34]. As for the citrate consumption test, all samples were negative, and these results were similar to the results of [35]. Red methylation and catalase test for all isolates were positive and the results converged with [36], while the results of the indole test showed that all isolates were positive and the results converged with [37]. As for The Voges-proskaur test, all isolates were negative. It matched with the results of [38]. As for the urease production test, all isolates under study were positive, it matched with the results of [37]. As for the gelatin test, all isolates were negative and it was similar to the results of [35]. The results of the oxidase test for collecting isolates were positive. The results matched with [39]. The table[5] also shows that when cultured groups of bacteria RhP, RhR. RPh, RhM, RhV, RhC, RhS,RhA, and RG isolated from nodules Pisum sativum, Vigna unguiculata, Phaseolus vulgaris, Trifolium spp, Vicia faba, Lens culinaris, Medicago sativa, Cicer arietinum L. and Trigomella faenumgraeum Plants respectively on Kings Medium.All these isolates had the ability to photoluminescence Fluoresce by exposure to UV rays at a wavelength of $320 \mathrm{~nm}$ and this result is almost identical to what was observed by researchers [35]. In this study of several strains of Rhizobium, the results showed that the selection of the medium of MacConky Agar on the previously mentioned isolates was positive and these results match what was indicated by both researchers [39]. As for the BTB test and the Congo red test, all isolates under study were positive, and this was indicated [40].

Table 5-A Shows the biochemical tests for isolates of Rhizobium bacteria.

\begin{tabular}{|c|c|c|c|c|c|c|c|c|c|c|c|c|c|c|c|c|}
\hline \multirow{2}{*}{$\begin{array}{l}\text {. Group of Rhizobium } \\
\text { Biochem Test }\end{array}$} & \multicolumn{4}{|c|}{$\underline{\mathbf{R h S}}$} & \multicolumn{4}{|c|}{ RhV } & \multicolumn{4}{|c|}{ RhC } & \multicolumn{4}{|c|}{$\mathbf{R h A}$} \\
\hline & 1 & 2 & 3 & 4 & 1 & 2 & 3 & 4 & 1 & 2 & 3 & 4 & 1 & 2 & 3 & 4 \\
\hline Catalase & + & + & + & + & + & + & + & + & + & + & + & + & + & + & + & + \\
\hline Oxidase & + & + & + & + & + & + & + & + & + & + & + & + & + & + & + & + \\
\hline Voges Proskaur & - & - & - & - & - & - & - & - & - & - & - & - & - & - & - & - \\
\hline MacConky Agar & + & + & + & + & + & + & + & + & + & + & + & + & + & + & + & + \\
\hline BTB & + & + & + & + & + & + & + & + & + & + & + & + & + & + & + & + \\
\hline Congo-rad & + & + & + & + & + & + & + & + & + & + & + & + & + & + & + & + \\
\hline Fluoresce & + & + & + & + & + & + & + & + & + & + & + & + & + & + & + & + \\
\hline Urease & + & + & + & + & + & + & + & + & + & + & + & + & + & + & + & + \\
\hline Citrate Utilization & - & - & - & - & - & - & - & - & - & - & - & - & - & - & - & - \\
\hline Gelatin liquefaction & - & - & - & - & - & - & - & - & - & - & - & - & - & - & - & - \\
\hline Indol production & + & + & + & + & + & + & + & + & + & + & + & + & + & + & + & + \\
\hline Motility & + & + & + & + & + & + & + & + & + & + & + & + & + & + & + & + \\
\hline Methyl Red & + & + & + & + & + & + & + & + & + & + & + & + & + & + & + & + \\
\hline Acid from glucose & + & + & + & + & + & + & + & + & + & + & + & + & + & + & + & + \\
\hline Acid from maltose & + & + & + & + & + & + & + & + & + & + & + & + & + & + & + & + \\
\hline Acid from ramenose & + & + & + & + & + & + & + & + & + & + & + & + & + & + & + & + \\
\hline Acid from lactose & + & + & + & + & + & + & + & + & + & + & + & + & + & + & + & + \\
\hline Acid from Galactose & + & + & + & + & + & + & + & + & + & + & + & + & + & + & + & + \\
\hline Acid from xylose & + & + & + & + & + & + & + & + & + & + & + & + & + & + & + & + \\
\hline
\end{tabular}

Test negative result (-) Test positive result $(+)$

Table 5-B Shows the biochemical tests for isolates of Rhizobium bacteria.

\begin{tabular}{|c|c|c|c|c|c|c|c|c|c|c|c|c|c|c|c|c|c|c|c|c|}
\hline \multirow{2}{*}{$\begin{array}{l}\text {. Group of Rhizobium } \\
\text { Biochem Test }\end{array}$} & \multicolumn{4}{|c|}{ RhG } & \multicolumn{4}{|c|}{ RhM } & \multicolumn{4}{|c|}{ Rhph } & \multicolumn{4}{|c|}{ RhP } & \multicolumn{4}{|c|}{ RhR } \\
\hline & 1 & 2 & 3 & 4 & 1 & 2 & 3 & 4 & 1 & 2 & 3 & 4 & 1 & 2 & 3 & 4 & 1 & 2 & 3 & 4 \\
\hline $\begin{array}{l}\text { Catalase } \\
\text { Oxidase }\end{array}$ & + & $\begin{array}{l}+ \\
+\end{array}$ & + & $\begin{array}{l}+ \\
+\end{array}$ & $\begin{array}{l}+ \\
+\end{array}$ & $\begin{array}{l}+ \\
+\end{array}$ & $\begin{array}{l}+ \\
+\end{array}$ & + & + & $\begin{array}{l}+ \\
+\end{array}$ & $\begin{array}{l}+ \\
+\end{array}$ & $\begin{array}{l}+ \\
+\end{array}$ & $\begin{array}{l}+ \\
+\end{array}$ & $\begin{array}{l}+ \\
+\end{array}$ & + & + & $\begin{array}{l}+ \\
+\end{array}$ & + & + & $\begin{array}{l}+ \\
+\end{array}$ \\
\hline Voges Proskaur & - & - & - & - & - & - & - & - & - & - & - & - & - & - & - & - & - & - & - & - \\
\hline
\end{tabular}




\begin{tabular}{l|cccccccccccccccccccc} 
MacConky Agar & + & + & + & + & + & + & + & + & + & + & + & + & + & + & + & + & + & + & + & + \\
BTB & + & + & + & + & + & + & + & + & + & + & + & + & + & + & + & + & + & + & + & + \\
Congo-rad & + & + & + & + & + & + & + & + & + & + & + & + & + & + & + & + & + & + & + & + \\
Fluoresce & + & + & + & + & + & + & + & + & + & + & + & + & + & + & + & + & + & + & + & + \\
Urease & + & + & + & + & + & + & + & + & + & + & + & + & + & + & + & + & + & + & + & + \\
Citrate Utilization & - & - & - & - & - & - & - & - & - & - & - & - & - & - & - & - & - & - & - & - \\
Gelatin liquefaction & - & - & - & - & - & - & - & - & - & - & - & - & - & - & - & - & - & - & - & - \\
Indol production & + & + & + & + & + & + & + & + & + & + & + & + & + & + & + & + & + & + & + & + \\
Motility & + & + & + & + & + & + & + & + & + & + & + & + & + & + & + & + & + & + & + & + \\
Methyl Red & + & + & + & + & + & + & + & + & + & + & + & + & + & + & + & + & + & + & + & + \\
Acid from glucose & + & + & + & + & + & + & + & + & + & + & + & + & + & + & + & + & + & + & + & + \\
Acid from maltose & + & + & + & + & + & + & + & + & + & + & + & + & + & + & + & + & + & + & + & + \\
Acid from ramenose & + & + & + & + & + & + & + & + & + & + & + & + & + & + & + & + & + & + & + & + \\
Acid from lactose & + & + & + & + & + & + & + & + & + & + & + & + & + & + & + & + & + & + & + & + \\
Acid from Galactose & + & + & + & + & + & + & + & + & + & + & + & + & + & + & + & + & + & + & + & + \\
Acid from xylose & + & + & + & + & + & + & + & + & + & + & + & + & + & + & + & + & + & + & +
\end{tabular}

Test negative result (-) Test positive result (+)

\section{Resistance and Sensitivity Test of Bacteria Isolated from Root Nodules to Antibiotics}

Ten antibiotics were selected to study their effects in terms of resistance and sensitivity of Rhizobium bacteria, Table 4 of these results was shown there are differences in sensitivity to antibiotics and can make groups of bacteria isolated from the root nodules of leguminous plants. Where it was noted that all bacteria isolates were $100 \%$ resistant to Trimethoprim and Streptomycin, as for the antibiotics Rifampicin and Tetracycline, the resistance was less than it was $22.2 \%$ among the groups of isolates understudy, while the percentage differences in resistance to other antibiotics of the bacterial isolates in the study amounted to $88.8 \%$ in Erythromycin and Amoxicillin, and in Nystatin the percentage reached 77.7\%, and the percentage in Ampicillin reached 77.7\%, while the percentage in Gentamycin was 33.3\%, and the percentage in Cefixime was $88.8 \%$. The results of this study were the same as what the researcher discovered [41]. In terms of the resistance of most of the isolates to the antibiotic Amoxicillin, where the results of Rhizobium resistance to Tetracycline,Streptomycin, Amoxicillin, and Ampicillin converged with many studies that indicated Rhizobium possessing resistance to these antibiotics and several isolates of Sinorhizobium meliloti and R. Leguminosarum, [42] [43]. There is also a difference in the percentage of antibiotic resistance in other groups of Rhizobium bacteria isolated from different regions, which are understudy.

Table 6 Resistance and sensitivity of Rhizobium bacteria isolated from leguminous plant nodules to antibiotics.

\begin{tabular}{|c|c|c|c|c|c|c|c|c|c|c|c|c|}
\hline \multicolumn{3}{|c|}{$\begin{array}{l}\text { Antibiotics } \\
\text { Final } \\
\text { conc. } \mu g / m l\end{array}$} & $\begin{array}{r}\text { Tet } \\
10\end{array}$ & $\begin{array}{r}\text { Cef } \\
50\end{array}$ & $\begin{array}{r}\text { Gen } \\
25\end{array}$ & $\begin{array}{r}\text { Amo } \\
\mathbf{5 0}\end{array}$ & $\begin{array}{r}\text { Tri } \\
50\end{array}$ & $\begin{array}{r}\text { Rif } \\
50\end{array}$ & $\begin{array}{r}\text { Amp } \\
\mathbf{5 0}\end{array}$ & $\begin{array}{l}\text { Str } \\
20\end{array}$ & $\begin{array}{r}\text { Nst } \\
50\end{array}$ & Ery \\
\hline \multirow{9}{*}{ 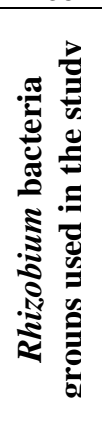 } & \multirow{5}{*}{$\underline{\mathbf{R h S}}$} & 1 & $\mathrm{~S}$ & $\mathrm{R}$ & $\mathrm{R}$ & $\mathrm{R}$ & $\mathrm{R}$ & $S$ & $R$ & $\mathrm{R}$ & $\mathrm{R}$ & $R$ \\
\hline & & 2 & S & $\mathrm{R}$ & $\mathrm{R}$ & $\mathrm{R}$ & $\mathrm{R}$ & $S$ & $\mathrm{R}$ & $\mathrm{R}$ & $\mathrm{R}$ & $\mathrm{R}$ \\
\hline & & 3 & S & $\mathrm{R}$ & $\mathrm{R}$ & $\mathrm{R}$ & $\mathrm{R}$ & S & $\mathrm{R}$ & $\mathrm{R}$ & $\mathrm{R}$ & $\mathrm{R}$ \\
\hline & & 4 & S & $\mathrm{R}$ & $\mathrm{R}$ & $\mathrm{R}$ & $\mathrm{R}$ & $S$ & $\mathrm{R}$ & $\mathrm{R}$ & $\mathrm{R}$ & $\mathrm{R}$ \\
\hline & & 1 & $\mathrm{R}$ & $\mathrm{R}$ & $S$ & $\mathrm{R}$ & $\mathrm{R}$ & $\mathrm{R}$ & $\mathrm{R}$ & $\mathrm{R}$ & $\mathrm{R}$ & $\mathrm{R}$ \\
\hline & \multirow{3}{*}{ RhV } & 2 & $\mathrm{R}$ & $\mathrm{R}$ & S & $\mathrm{R}$ & $\mathrm{R}$ & $\mathrm{R}$ & $\mathrm{R}$ & $\mathrm{R}$ & $\mathrm{R}$ & $\mathrm{R}$ \\
\hline & & 3 & $\mathrm{R}$ & $\mathrm{R}$ & S & $\mathrm{R}$ & $\mathrm{R}$ & $\mathrm{R}$ & $\mathrm{R}$ & $\mathrm{R}$ & $\mathrm{R}$ & $\mathrm{R}$ \\
\hline & & 4 & $\mathrm{R}$ & $\mathrm{R}$ & $S$ & $\mathrm{R}$ & $\mathrm{R}$ & $\mathrm{R}$ & $\mathrm{R}$ & $\mathrm{R}$ & $\mathrm{R}$ & $\mathrm{R}$ \\
\hline & RhC & 1 & $S$ & $\mathrm{R}$ & $S$ & $\mathrm{R}$ & $\mathrm{R}$ & $S$ & $\mathrm{R}$ & $\mathrm{R}$ & $\mathrm{R}$ & $\mathrm{R}$ \\
\hline
\end{tabular}




\begin{tabular}{|c|c|c|c|c|c|c|c|c|c|c|c|}
\hline & 2 & S & $\mathrm{R}$ & $S$ & $\mathrm{R}$ & $\mathrm{R}$ & $S$ & $\mathrm{R}$ & $\mathrm{R}$ & $\mathrm{R}$ & $\mathrm{R}$ \\
\hline & 3 & S & $\mathrm{R}$ & S & $\mathrm{R}$ & $\mathrm{R}$ & S & $\mathrm{R}$ & $\mathrm{R}$ & $\mathrm{R}$ & $\mathrm{R}$ \\
\hline & 4 & S & $\mathrm{R}$ & S & $\mathrm{R}$ & $\mathrm{R}$ & $S$ & $\mathrm{R}$ & $\mathrm{R}$ & $\mathrm{R}$ & $\mathrm{R}$ \\
\hline \multirow{5}{*}{$\mathbf{R h} \mathbf{A}$} & 1 & $S$ & $\mathrm{R}$ & $S$ & $\mathrm{R}$ & $\mathrm{R}$ & $S$ & $\mathrm{R}$ & $\mathrm{R}$ & $\mathrm{R}$ & $\mathrm{R}$ \\
\hline & 2 & $S$ & $\mathrm{R}$ & $S$ & $\mathrm{R}$ & $\mathrm{R}$ & $S$ & $\mathrm{R}$ & $\mathrm{R}$ & $\mathrm{R}$ & $\mathrm{R}$ \\
\hline & 3 & $S$ & $\mathrm{R}$ & $\mathrm{S}$ & $\mathrm{R}$ & $\mathrm{R}$ & $S$ & $\mathrm{R}$ & $\mathrm{R}$ & $\mathrm{R}$ & $\mathrm{R}$ \\
\hline & 4 & $S$ & $\mathrm{R}$ & $S$ & $\mathrm{R}$ & $\mathrm{R}$ & $S$ & $\mathrm{R}$ & $\mathrm{R}$ & $\mathrm{R}$ & $\mathrm{R}$ \\
\hline & 1 & $S$ & $S$ & $S$ & $\mathrm{R}$ & $\mathrm{R}$ & $S$ & $S$ & $\mathrm{R}$ & $S$ & $S$ \\
\hline \multirow{3}{*}{ RhG } & 2 & S & S & S & $\mathrm{R}$ & $\mathrm{R}$ & S & $S$ & $\mathrm{R}$ & $S$ & $S$ \\
\hline & 3 & $S$ & $S$ & $S$ & $\mathrm{R}$ & $\mathrm{R}$ & $S$ & $S$ & $\mathrm{R}$ & $\mathrm{S}$ & $\mathrm{S}$ \\
\hline & 4 & $S$ & $S$ & $S$ & $\mathrm{R}$ & $\mathrm{R}$ & $S$ & $S$ & $\mathrm{R}$ & $S$ & $S$ \\
\hline \multirow{4}{*}{ RhM } & 1 & $\mathrm{R}$ & $\mathrm{R}$ & $S$ & $S$ & $\mathrm{R}$ & $S$ & $\mathrm{R}$ & $\mathrm{R}$ & $S$ & $\mathrm{R}$ \\
\hline & 2 & $S$ & $\mathrm{R}$ & $S$ & $S$ & $\mathrm{R}$ & $S$ & $\mathrm{R}$ & $\mathrm{R}$ & $S$ & $\mathrm{R}$ \\
\hline & 3 & $S$ & $\mathrm{R}$ & $S$ & $S$ & $\mathrm{R}$ & $S$ & $\mathrm{R}$ & $\mathrm{R}$ & $S$ & $\mathrm{R}$ \\
\hline & 4 & $S$ & $\mathrm{R}$ & $S$ & $S$ & $\mathrm{R}$ & $S$ & $\mathrm{R}$ & $\mathrm{R}$ & $S$ & $\mathrm{R}$ \\
\hline \multirow{4}{*}{ Rhph } & 1 & $S$ & $\mathrm{R}$ & $\mathrm{R}$ & $\mathrm{R}$ & $\mathrm{R}$ & $S$ & $\mathrm{R}$ & $\mathrm{R}$ & $\mathrm{R}$ & $\mathrm{R}$ \\
\hline & 2 & $S$ & $\mathrm{R}$ & $\mathrm{R}$ & $\mathrm{R}$ & $\mathrm{R}$ & $S$ & $\mathrm{R}$ & $\mathrm{R}$ & $\mathrm{R}$ & $\mathrm{R}$ \\
\hline & 3 & $S$ & $\mathrm{R}$ & $\mathrm{R}$ & $\mathrm{R}$ & $\mathrm{R}$ & $S$ & $\mathrm{R}$ & $\mathrm{R}$ & $\mathrm{R}$ & $\mathrm{R}$ \\
\hline & 4 & $S$ & $\mathrm{R}$ & $\mathrm{R}$ & $\mathrm{R}$ & $\mathrm{R}$ & $S$ & $\mathrm{R}$ & $\mathrm{R}$ & $\mathrm{R}$ & $\mathrm{R}$ \\
\hline \multirow{4}{*}{ RhP } & 1 & $\mathrm{~S}$ & $\mathrm{R}$ & $S$ & $S$ & $\mathrm{R}$ & $S$ & $\mathrm{R}$ & $\mathrm{R}$ & $\mathrm{R}$ & $\mathrm{R}$ \\
\hline & 2 & $S$ & $\mathrm{R}$ & $S$ & $S$ & $\mathrm{R}$ & $S$ & $\mathrm{R}$ & $\mathrm{R}$ & $\mathrm{R}$ & $\mathrm{R}$ \\
\hline & 3 & S & $\mathrm{R}$ & S & S & $\mathrm{R}$ & S & $\mathrm{R}$ & $\mathrm{R}$ & $\mathrm{R}$ & $\mathrm{R}$ \\
\hline & 4 & $S$ & $\mathrm{R}$ & $S$ & $S$ & $\mathrm{R}$ & $S$ & $\mathrm{R}$ & $\mathrm{R}$ & $\mathrm{R}$ & $\mathrm{R}$ \\
\hline \multirow{4}{*}{ RhR } & 1 & $\mathrm{R}$ & $\mathrm{R}$ & $\mathrm{R}$ & $\mathrm{R}$ & $\mathrm{R}$ & $\mathrm{R}$ & $S$ & $\mathrm{R}$ & $\mathrm{R}$ & $\mathrm{R}$ \\
\hline & 2 & $\mathrm{R}$ & $\mathrm{R}$ & $\mathrm{R}$ & $\mathrm{R}$ & $\mathrm{R}$ & $\mathrm{R}$ & $S$ & $\mathrm{R}$ & $\mathrm{R}$ & $\mathrm{R}$ \\
\hline & 3 & $\mathrm{R}$ & $\mathrm{R}$ & $\mathrm{R}$ & $\mathrm{R}$ & $\mathrm{R}$ & $\mathrm{R}$ & $S$ & $\mathrm{R}$ & $\mathrm{R}$ & $\mathrm{R}$ \\
\hline & 4 & $\mathrm{R}$ & $\mathrm{R}$ & $\mathrm{R}$ & $\mathrm{R}$ & $\mathrm{R}$ & $\mathrm{R}$ & $S$ & $\mathrm{R}$ & $\mathrm{R}$ & $\mathrm{R}$ \\
\hline
\end{tabular}

The emergence of the characteristic of resistance $(R)$ The emergence of the characteristic of sensitivity (S)

\section{Resistance and Sensitivity Test of Bacteria Isolated from Root Nodules to Heavy Metal:}

By looking at the table-7 groups of Rhizobium bacteria that isolated from the root nodules of leguminous plants showed that among isolates were resistant to cobalt chloride $\left(\mathrm{CoCl}_{2}\right)$ and $\left(\mathrm{CdCl}_{2}\right)$ at $94.4 \%$. As for the percentage of the resistance of these aggregates to the heavy metal $\mathrm{HgCl}_{2}$ was $77,7 \%$ while the percentage of resistance of these aggregates to heavy metal nickel chloride $\left(\mathrm{NiCl}_{2}\right)$ was $55.5 \%$. The results showed that the isolates in $(\mathrm{RhV})$ had a very high resistance that recodes $100 \%$ of the percentage of all heavy metals used in the study, While the remaining bacterial groups were $\mathrm{RhA}, \mathrm{RhS}, \mathrm{RhG}, \mathrm{RhC}, \mathrm{RhPh}$, $\mathrm{RhM}, \mathrm{RhP}, \mathrm{RhR}$ which isolates from the nodes, The roots of plants: Vigna unguiculata, Pisum sativum, Trifolium spp, Phaseolus vulgaris,Lens culinaris,Trigonella foenum- graeum, Medica go sativa and Cicer arietinum, respectively, the resistance to heavy metals was disparate The bioaccumulation of heavy metals and their toxicity in the environment affect the life of living organisms tremendously, as heavy metals cannot be broken down through chemical and biological processes, which is the opposite of organic pollutants, but it can turn into lower toxic types. to withstand heavy metals from several polluted industrial areas. Minerals affected their protein profiles and most of the changes were offset by a decrease in the expression of polypeptides. This study indicated that there is a relationship between root tolerance and soil contamination with heavy metals and change in protein pool as a result, analysis of protein changes appears to be a good indicator for estimating the level of stress imposed on Rhizobium groups exposed to 
contamination. with heavy metals. The long-term deposition of minerals in the soil resulted in high concentrations of minerals, which negatively affects the microorganisms in the soil [44]

Table 7-Resistance and sensitivity of Rhizobium bacteria isolated from nodules of leguminous plants to heavy metals.

\begin{tabular}{|c|c|c|c|c|c|c|}
\hline \multicolumn{3}{|c|}{$\begin{array}{c}\text { Heavy Metals } \\
\text { Final conc. } \mu \mathrm{g} / \mathrm{ml}\end{array}$} & $\begin{array}{c}\mathrm{NiCl}_{2} \\
\mathbf{2 5} \\
\end{array}$ & $\begin{array}{c}\mathrm{HgCl}_{2} \\
\mathbf{2 5} \\
\end{array}$ & $\begin{array}{c}\mathrm{CoCl}_{2} \\
25 \\
\end{array}$ & $\begin{array}{c}\mathrm{CoCl}_{2} \\
25 \\
\end{array}$ \\
\hline \multirow{36}{*}{ 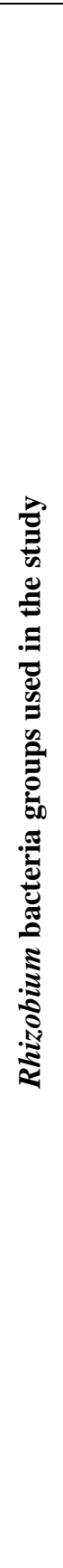 } & \multirow{4}{*}{$\underline{\mathbf{R h S}}$} & 1 & ++ & ++ & +++ & ++ \\
\hline & & 2 & ++ & ++ & +++ & ++ \\
\hline & & 3 & ++ & ++ & +++ & ++ \\
\hline & & 4 & ++ & ++ & +++ & ++ \\
\hline & \multirow{4}{*}{$\mathbf{R h V}$} & 1 & +++ & +++ & +++ & +++ \\
\hline & & 2 & +++ & +++ & +++ & +++ \\
\hline & & 3 & +++ & +++ & +++ & +++ \\
\hline & & 4 & +++ & +++ & +++ & +++ \\
\hline & \multirow{4}{*}{$\mathbf{R h C}$} & 1 & + & ++ & + & ++ \\
\hline & & 2 & + & ++ & + & ++ \\
\hline & & 3 & + & ++ & ++ & ++ \\
\hline & & 4 & + & ++ & ++ & +++ \\
\hline & \multirow{5}{*}{ RhA } & 1 & +++ & + & ++ & +++ \\
\hline & & 2 & +++ & + & ++ & +++ \\
\hline & & 3 & +++ & + & ++ & +++ \\
\hline & & 4 & +++ & + & ++ & +++ \\
\hline & & 1 & + & ++ & +++ & ++ \\
\hline & \multirow{3}{*}{ RhG } & 2 & + & ++ & +++ & ++ \\
\hline & & 3 & + & ++ & +++ & ++ \\
\hline & & 4 & + & ++ & +++ & ++ \\
\hline & \multirow{5}{*}{$\mathbf{R h M}$} & 1 & + & +++ & ++ & ++ \\
\hline & & 2 & + & +++ & ++ & ++ \\
\hline & & 3 & + & +++ & ++ & ++ \\
\hline & & 4 & + & +++ & ++ & ++ \\
\hline & & 1 & ++ & ++ & +++ & +++ \\
\hline & \multirow{3}{*}{ Rhph } & 2 & ++ & ++ & +++ & +++ \\
\hline & & 3 & ++ & ++ & +++ & +++ \\
\hline & & 4 & ++ & ++ & +++ & +++ \\
\hline & \multirow{4}{*}{$\mathbf{R h P}$} & 1 & ++ & + & ++ & ++ \\
\hline & & 2 & ++ & + & ++ & ++ \\
\hline & & 3 & ++ & + & ++ & + \\
\hline & & 4 & ++ & + & ++ & + \\
\hline & \multirow{4}{*}{ RhR } & 1 & + & ++ & +++ & +++ \\
\hline & & 2 & + & ++ & +++ & +++ \\
\hline & & 3 & + & ++ & +++ & +++ \\
\hline & & 4 & + & ++ & +++ & +++ \\
\hline
\end{tabular}

High resistance (+++) Medium resistance (++) Weak resistance (+)[45]

The researchers conducted [44] a study in which Rhizobium leguminosarum biovar viciae was isolated from areas was different contents of minerals and their variances were apportioned pool in 
Rhizobium groups were also evaluated. Physical and chemical parameters were determined and mineral concentrations were analyzed in soil by ICP-AES-isolates were screened for tolerance in YEMA supplemented with different heavy metals $(\mathrm{Zn}, \mathrm{Pb}, \mathrm{Co}, \mathrm{Cd}, \mathrm{Ni}$, and $\mathrm{Cr}$ ). The proteins were extracted and separated by SDS-PAGE soil (EI and EL Engineering industries) Presented the highest concentration of minerals and thus the soil was more contaminated. The isolates showed different growth responses (Control) and $\mathrm{M}$ (Mines) were less tolerant than isolates of $\mathrm{EI}_{1}, \mathrm{EI}_{2}$, and $\mathrm{C}_{1}$ (Chemical industries). The change in protein pool as a consequence analysis of protein changes appears to be a good indicator for estimating the level of stress imposed on Rhizobia populations exposed to heavy metal contamination.

\section{Study and characterization of the genetic content of rhizobia bacteria understudy}

Extraction of DNA content from groups of Rhizobia bacteria isolated from leguminous plants. The process of electrophoresis of the extracted genomic DNA samples was carried out using agarose gel a with concentration (1\%) using UV rays and Gel Documentation, gel imaging was performed to trace and detect the genomic DNA bands. Figure 2 - shows the results of the detection, also shows that the genomic DNA bundles appeared in equal and larger sizes as a result of their proximity to the etching of the agarose gel.

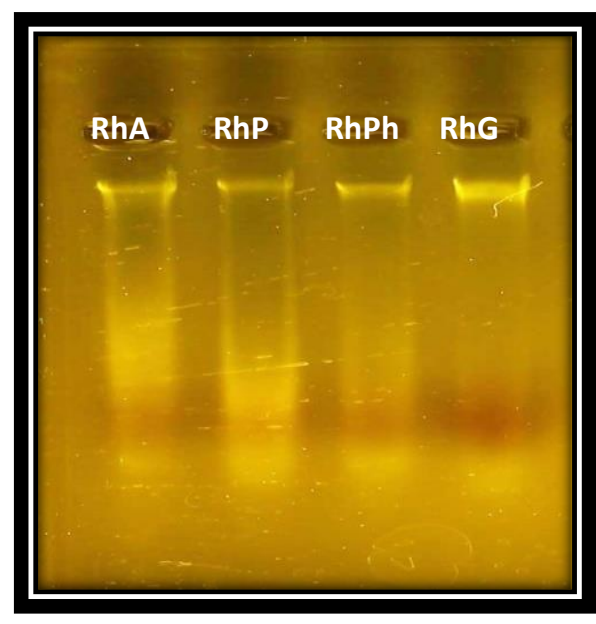

Figure 2-The Electrophoresis in agarose at a concentration of $0.7 \%$ of the genomic DNA.

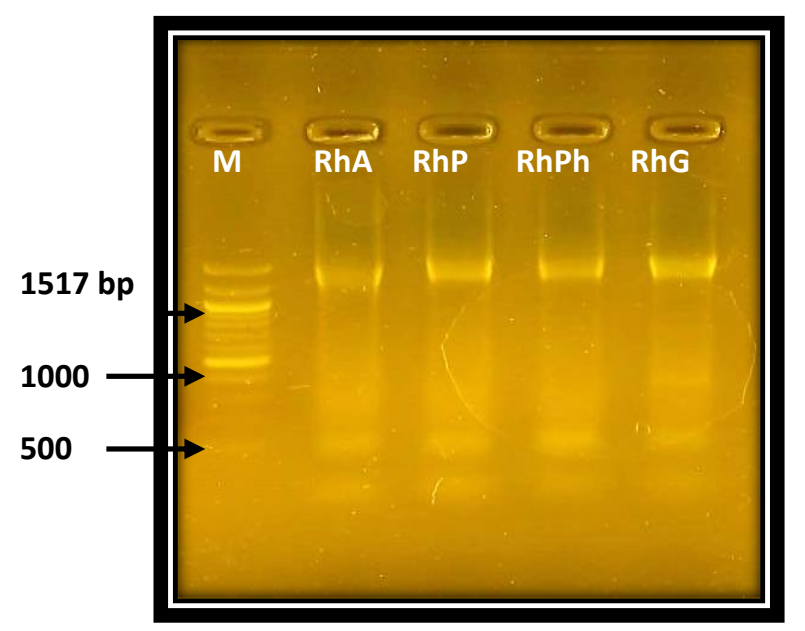

Figure 3-The Electrophoresis in agarose at a concentration of $0.1 \%$ of the PCR Products to $16 \mathrm{~S}$ rRNA of Rhizobium isolates

\section{S rRNA partial sequencing of the gene:}

Figure -3. it was present concluded that there are four amplified bundles of the genomic DNA site, prepared from the isolates of Rhizobia bacteria under study ( $\mathrm{RhA}, \mathrm{RhP}, \mathrm{RhPh}, \mathrm{RhG})$, appear as results of gel electrophoresis of PCR product to all isolates which were equal and large range about of $1500 \mathrm{bp}$. The reason for the emergence of these bundles of pure DNA is the result of the presence of a common sequence of the nucleotide present in the DNA of these bacterial groups, where this similarity enabled them to complement the nitrogenous bases in the specialized primers, the completion reaction and the production of DNA bundles of large and equal sizes this was similar were found in the researches were reported by researchers through their study on 25 selected isolates of (Phaseolus vulgaris L.), where PCR amplification of 16S rRNA genes produced a single $1500 \mathrm{bp}$ sequences. Sequences were deposited in a bank and their access numbers were determined. The newly obtained $16 \mathrm{~S}$ rRNA fragment with known bacterial sequences in the genebank database using BLASTN analysis showed sequence similarity to nitrogenous bases with a percentage of $99.2 \%$ [46] and [47]. Genetic analysis was conducted for four randomly selected isolates using the sequences obtained from DNA sequencing technology by using the 
Mole-Blast program through the link NIH.Govto find the phylogenic tree of the genotypes that shows the genetic relationship between the Rhizobium isolates under study and the standard strains registered in the gene bank, The results of this study are close to the findings of the research [10] when they studied the genetic diversity often isolates of Rhizobium leguminosarum bacteria in Egypt.

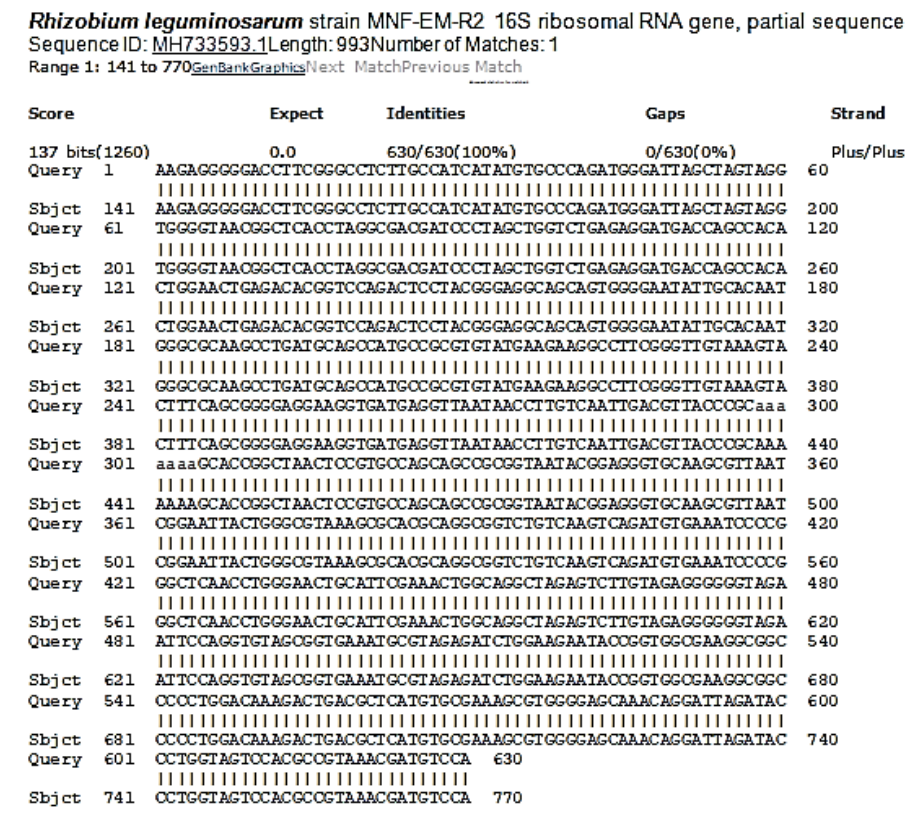

Fig 4- Comparison of the nitrogenous base sequences of the local isolate (RhG) and the major strain : MH733593.1

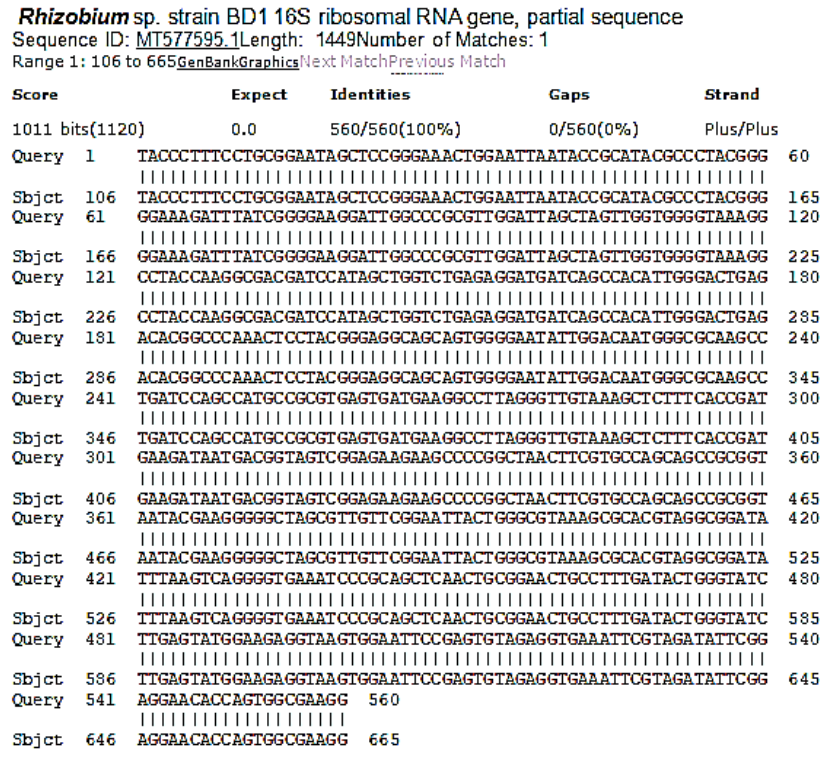

Fig 5- Comparison of the nitrogenous base sequences of the local isolate (RhA) and the major strain : MT577595.1

\begin{abstract}
Paraburkholderia nodosa strain UFLA01-786 16S ribosomal RNA gene, partial sequence Sequence ID: MK649682.1Length: 1073Number of Matches: 1

Range 1: 173 to 661 GenBankGraphics Next MatchPrevious Match

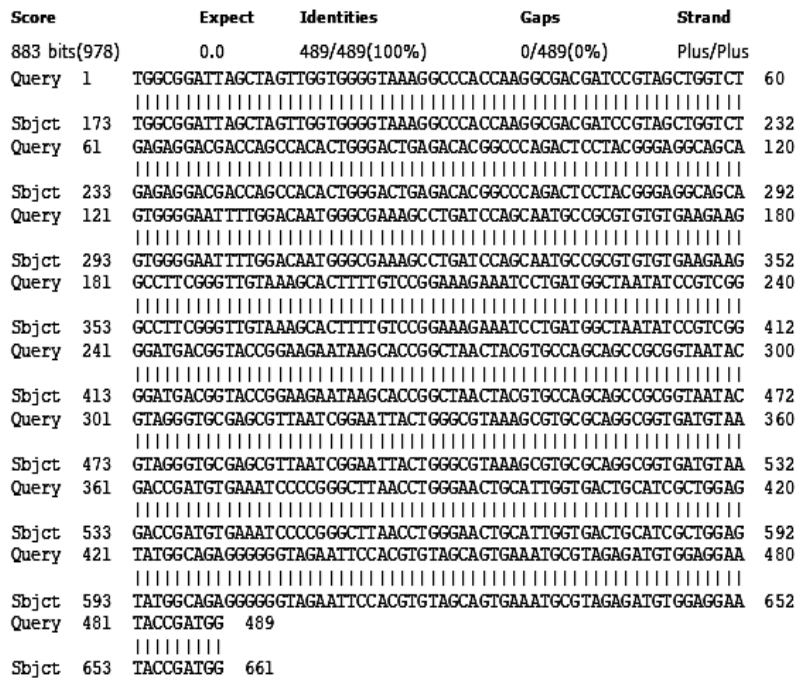

Fig 6- Comparison of the nitrogenous base sequences of the local isolate $(\mathrm{RhPh})$ and the major strain : MK649682.1

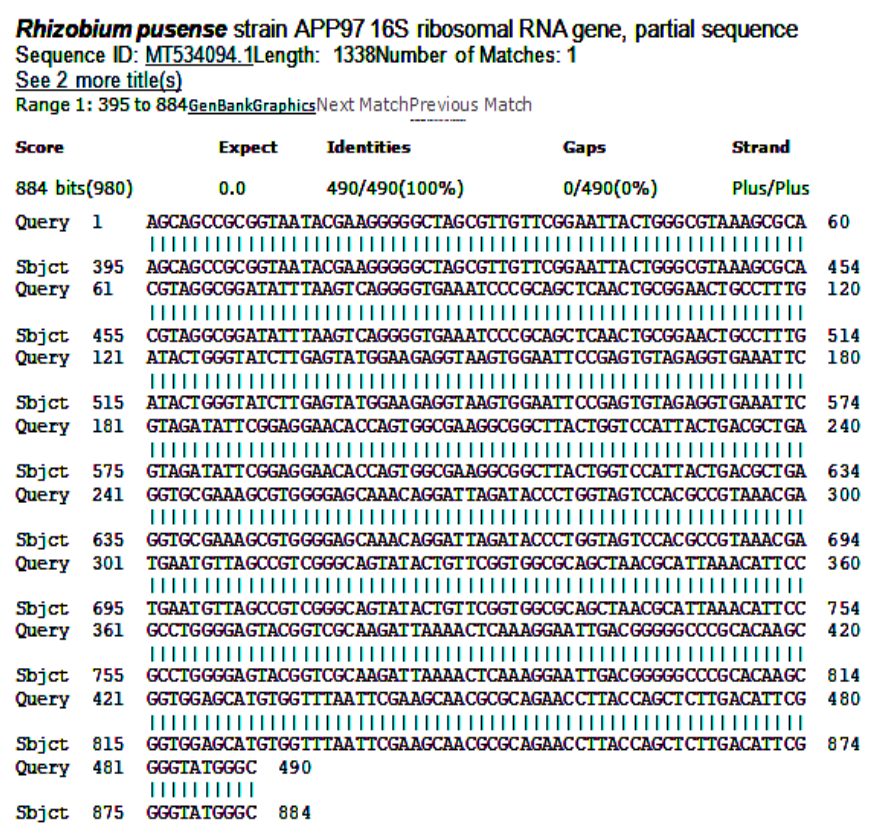

Fig 7- Comparison of the nitrogenous base sequences of the local isolate (RhP) and the major strain : MT534094.1 


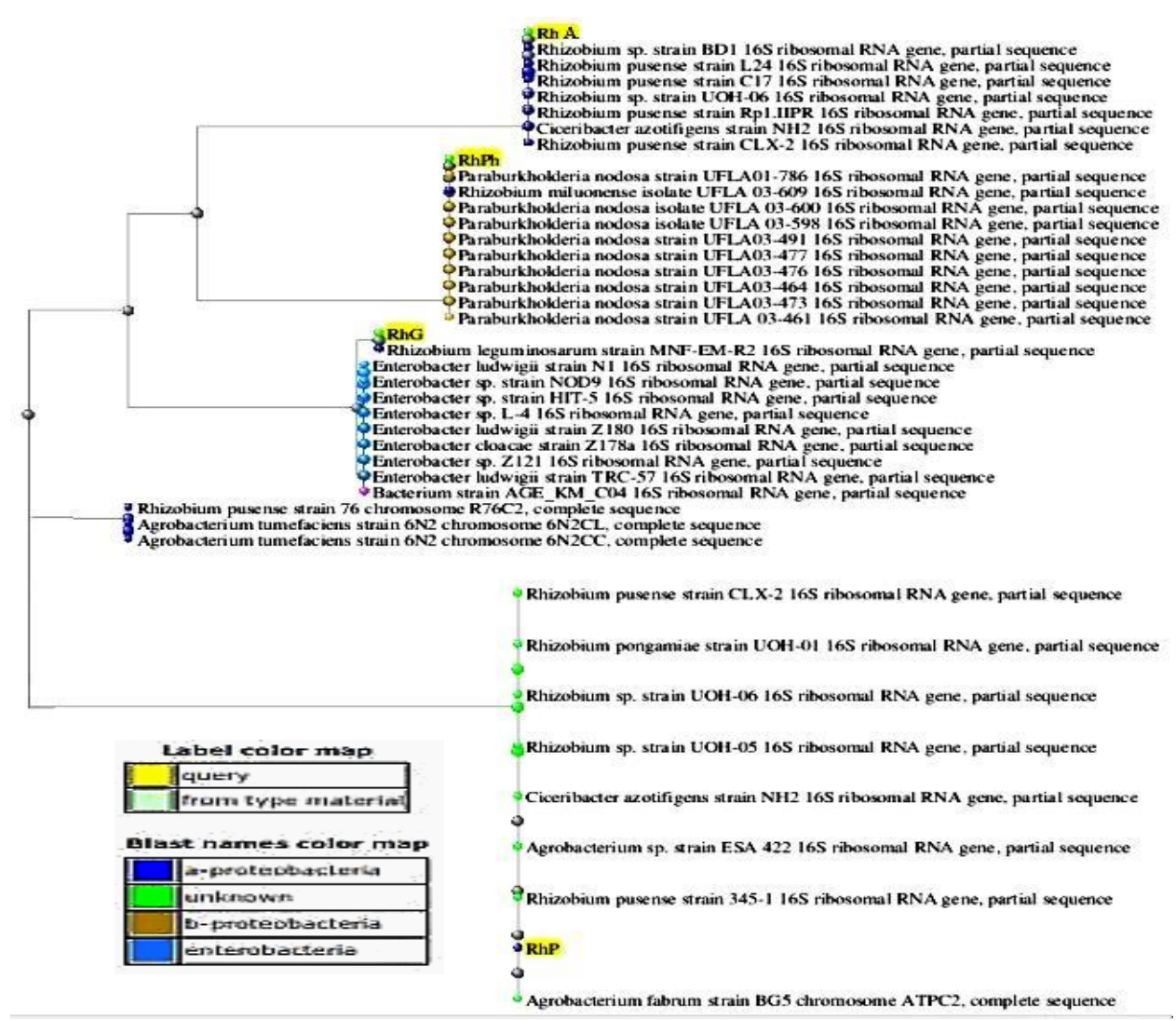

Figure 8- shows the Phylogenic tree of the genotypes using the results of the sequence analysis of four Rhizobium isolates under study and using the program Mole/ Blast

\section{Conclusion}

By observing the results of the analysis using the DNA program, it showed that there is a great similarity of up to $100 \%$ between the sequences of the bacterial isolates under study (RhA, $\mathrm{RhP}, \mathrm{RhPh}, \mathrm{RhG})$. With the sequences of the nitrogenous bases of the standard bacterial isolates Rhizobium sp. strain BD1, Rhizobium presence strain APP97, Paraburkholderia nodosa strain UFLA01-786, and Rhizobium leguminosarum strain MNF-EM-R2 (MT577595.1, MT534094.1, MK649682.1, and MH733593.1) respectively and recorded in the NCBI GenBank.Figure 8, shows the DNA Blast/ NCBI program for nitrogen base analysis of bacterial isolation, the isolates in this study (RhA) were recorded as standard strain in The GenBank (NCBI) and given the accession number LC635720.1. Rhizobium pusense SAM-MA. Through the results obtained, it is clear that the possibility of genetic transfer of genes related to the process of fixing atmospheric nitrogen is the transfer between members of bacterial species through horizontal transfer of genetic traits between bacterial cells, and this is what the researchers also noticed by isolating Rhizobium bacteria in Egypt By studying the genetic variance of the genetic sequence of the 16S rRNA site and making a comparison between bacterial species [10].

\section{Acknowledgments:}

This study was carried out by the Department of biology/ College of Education and Pure Sciences University of Mosul / Iraq and with the support of the Genomic DNA Laboratory in Mosul / Iraq.

\section{Conclusion:}

We concluded from our current study that there is the possibility of studying the genetic similarity between genetic isolates and isolates from different regions by using PCR technique by studying the 


\section{Journal of Education and Science (ISSN 1812-125X), Vol: 30, No: 5, 2021 (163-177)}

sequence of nitrogenous bases of the $16 \mathrm{~S}$ rRNA gene, which helps in diagnosing local isolates and the possibility of using them in finding isolates that were recorded for the first time in Nineveh Governorate as standard strain in The GenBank (NCBI) and given the accession number LC635720.1 Rhizobium pusense SAM-MA.

\section{References}

1. B. Lyer and S. Rajkumar "Rhizobia. In Reference Module in Life Sciences" Elsevier, Nirma University, p: 120.2019. DOI:10.1016/B978-0-12-809633-8.13104-8

2. M. J. Dilworth, K. E. James, J. I. Sprent,"Newton, W.E.(eds.) Nitrongen fixing leguminous. Netherlands" pp. 1 18. 2008. http://www.springer.com/gp/book/9781402035456

3. C. Franche, K. Lindstrom and C. Elmerich, "Nitrogen-fixing bacteria associated with leguminous and nonleguminous plants." Plant and Soil, 321:35-59.2009. http://doi:10.1007/s11104-008-9833-8

4. S. Pervin, B. Jannat, S. Alsanjee, and T. Farzana,"Characterization of Rhizobia from Root Nodule and Rhizosphere of Lablab purpureus and Vigna sinensis in Bangladesh" Turkish J. of Agriculture Food Sci. Technol., 5(1):14-17.2017 DOI: 10.24925/turjaf.v5i1.14-17.743

5. J. L.Setu, B. Ahmed, and Q. K. Kibria, "Identification and Characterization of rhizobium” Int. J. Res. Anal. Rev., 6(2):519-527.2019.

6. Sprent. J. I. "Nodulation in Legumes."Royal Botanic Gardens, Kew, United Kingdom, 89(6):797-798 2001.

7. I. N. Khalil. and A. Abdel Ghafoor,"Measurement of the activity of cellulase enzyme produced by root gangline bacteria." Tikrit J. Pure Sci, (16) (2):188-193.(In Arabic). Iraq. 2011.

8. M. Andrews, and E. M. Andrews, "Specificity in Legume-Rhizobia Symbioses," Int. J. Mol. Sci. 18(705):139.vb.2017. DOI: 10.3390/ijms18040705

9. H. Berrada, and K. Fikri-Benbrahim "Taxonomy of the Rhizobia: Current perspectives". British Microbiol. Res. J. 4(6): 616-639. 2014. DOI: doi.org/10.9734/BMRJ/2014/5635.

10. M. Ismail. M. Adblfattah. El-Zanatay, A. Ragaa. Eissa, and A.O. Hewedy, "Genetic Diversity of Rhizobium leguminosarum as Revealed by 16S rRNA Gene Sequence" American-Euraslan J. Agric. and Environ. Sci., 13(6): 797-801.2013. 10e.xps (idosi.org)

11.B. Jha, M. Thakur, I. Gontia, V. Albrecht, M. Stoffels, M. Schmid, A. Hartmann, "Isolation. Partial identification and application of diazotrophic rhizobacteria from traditional Indian rice cultivars," European Journal of Soil Biology.1(45). 62-72.2008. https://doi.org/10.1016/j.ejsobi.2008.06.007

12. Al-Saffar. Fowze Abdel Salam."Salection of isolates of Sinorhizobium meliloti and Rhizobium leguminosarum bv. Salinity and acid tolerant trifoli. Master Thesis. College of Education. University of Mosul. Iraq. 2005.

13.Sharif. Intether Thanun Ahmed."Study of the factors affecting the production of exogenous polysaccharides of Rhizobia bacteria and its effects on the phenotypic Profiles of Medicago sativa. Master Thesis. College of Education. University of Mosul.Iraq.2008.

14. A. Petit, J. Stougaard, A. Kuhle, A. K. Marcher and J. Tempe "Transformation and regeneration of Legume Lotus cornicculatus: A system for molecular Studies of Symbiotic nitrogen fixation. "Mol. Gen.Genet.,207:245250.1987. https://doi.org/10.1007/BF00331585.

15. A. M. J. Vincet "Manual for the Practial Study of Root Nodule Bacteria" IBP Handbook No.15.Oxford: Black well Scientific Publications, Oxford, p.113-131.1970.

16. Graham. P. H, "Selective Medium Rhizobium" Appl. Microboil. DOI: 10.1128/am.17.5.769-770.1969

17. B. Singh, R. Kaur, and K. Singh, J. "Characterization of Rhizobium strain isolated from the roots of Trigonella foenumgraecum ( fenugreek)."Afr. J. Biotech., Vol. 7(20):pp. 3671-3676.2008. https://www.researchgate.net/publication/228770496

18. G.Fahraeus, "The infection of clover hairs by nodule bacteria studied by simple glass slide technique"J. Gen. Microbiol. 374-381 (1957). DOI: 10.1099/00221287-16-2-374 


\section{Journal of Education and Science (ISSN 1812-125X), Vol: 30, No: 5, 2021 (163-177)}

19. J. A.Grant, and J. Pittard, "Incompatibility reactions of R-plasmid isolated from Escherichia coli of animal origin. Journal of Bacteriology. https://doi.org/10.1128/jb.120.1.185-190.1974.

20. K. N. Timmis and A. Pühler "Advanced Molecular Genetics" Springer-Verlarg.Berlin Heidelberg. New York Tokyo 1984. Advanced Molecular Genetics | Alfred Puehler|Springer.

21. Ahmed, K. Dham "The Positive Control of live expression in E.coli K-12" Ph. D. Thesis, Univ. Durham.England.1989 .A thesis submitted to the University of Durham for the degree of Doctor of Philosophy. http://etheses.dur.ac.uk/6314

22. Z. Wadhwa, V. Srivastava, R. Rani, Tanvi, K. Makkar, and S. Jangra "Isolation and characterization of Rhizobium from Chickpea (Cicer arietinum)" Int. J. Curr. Microbiol. App. Sci. 6(11): 2880-2893.2017. DOI: $\underline{10.20546 / i j c m a s .2017 .611 .340 ~}$

23.S.G.Deoea, and K. Singhal "Isolation. biochemical characterization and preparation of biofertilizers using Rhizobium strains for commercial use,"Int. Sci. J., 3(2): 132-136.2010. 115 page se.pdf (bbrc.in)

24.K. T. Chhetri, B. R. Subedee, and B. Pant "Isolation, Identification and Production of Encapsulated Bradyrhizobium japonicum and Study on their Viability" Nep.J. Biotechnol., 7(1): 39-49 2019. DOI: $10.3126 /$ njb.v7i1.26950

25.W. E. Konema's,D. S. Allen, M. W. Janada, C. P. Schreckenberger, and C. W. Winn "Color atlas and Text Book of Diagnostic Microbiology. $5^{\text {th }}$ ed.” J. B. Lippincott Com., Philadelphia. U. S. A.1997.

26. J. H. Benson "Microbiological" $8^{\text {th }}$ ed., McGraw Hill Companies, Inc., p.130-155(2002).

27. Prescott, M. L., P. J. Harley and A. D. Klein. "Microbiology". 5th edition. McGraw Hill Companies Inc., New York. pp. 919 - 923. (2002).

28., De la Maza, M. L., T. M. Pezlo, and, J. E. Baron "Color Atlas Of Diagnostic Microbiology". Mosby Year Book, United Starts of America, p.25-92(1997). https://www.scribd.com/doc/305092099/Color-Atlas-ofDiagnostic-Microbiology

29. P. D. Beck, A. L. Materon, and F. Afandi, "Practical Rhizobium Legume technology manual" Technical. manual. No19. ICARDA.1993. https://agris.fao.org/agris-search/search.do?recordID=QV930023

30. M. Ronald, Atlas "The Handbook of Microbiogical Media for the examination of food" $2^{\text {th }}$ ed., Taylor and Francis Group. pp. (276-277). 2006. https://doi.org/10.1201/9781420002980

31.C.L.Kado, and S.T Liu. Rapid procedure for detection and isolation of large and small plasmids. J.Bacteriol., (1981) 145(3):1365-1373.

32. N. Selami, C. M. Auriae, O. Catrice, D. Capela, K. M. Harche and T. Timmers "Morphology and anatomy of root nodules of Retama monosperma (L.)” Boiss. J. Plant_Soil, 379(1-2). 109-119 (2014). Doi.10.1007/811104014-2045-5. https://www.jstor.org/stable/42952818

33. A. Adiguzel, H. Ogutcu, O. Baris, M. Karadayi, M. Gulluce, and Sahin, F. "Isolation and Characterization of Rizobium Stranis from Wild Vetch Collected From High Altitudes in Erzurum_Turkey" Romanian Biotechnological Letters. Vol.15(1):5017.2010.E-mail: adiguzel@atauni.e du.tr and adiguzel25@ gmail.com

34. C. Bhattacharya, B. Deshpande, and B. Pandy, "Isolation and Characterization of Rhizobium spp. Form Root of Legume plant (Pisum sativum) and Its Antibacterial Activity against Different Bacterial strains. "Int. J. Agri. Food Scie., 3(4):138-141. 2013 https://www.researchgate.net/publication/349310911.

35. B. Singha, P. Das, B. P. Masumder "Morphological and Biochemical Characterization of Rhizobium Isolated from Root Nodule of Crotolaria junceae L. Grown in Assam" In. J. Sci. Rese 4.4382013. http://www.ijsr.net

36. D. Roychowdhury, M. Paul, and K. S. Banerjee "Isolation identification and characterization of bacteria (Rhizobium) from chick pea (Cicer arietinum) and production of biofertilizer" Euro. J. Biotech. and Biosc., 3(12):26-29 (2015). https://www.researchgate.net/publication/301799385

37. A. T. Hamza, and L. A. Alebejo, "Isolation and Characterization of Rhizobia from Rhizosphere and Root Nodule of Cowpea, Elephant and Lab Lap Pants”. Int. J.Novel Res. In Interdisciplinary Studies, 4(4): 1-7.2017. www.noveltyjournals.com 
38.A.panwar,S. Choudhary,M. Sharma,K.Y. Shrama,S.R. Meena,S.K. Malhotra, S.R.Mehta, andO.P.Aishwath,"Morphological and biochemical characterization of Rhizobium isolates obtained from fenugreek (Trigonella fronum). "Seed Res., Vol. 40(2): 196-200.2013.

39. N. N. B. Kumari, B. Nagaraju, and K. Mallkarjune,"Biochemical characterization and protein profile By SDSPage of French Bean (Phaseolus vulgaris L.) associated Rhizobia” Innovat Int. J. Med. Pharm. Sci., 2(2): 8-13. 2017.

40.G. Koskey, SW. Mburu, MJ. Kimiti, O. Ombori, JM.Maingi, and EM.Njeru, "Genetic Characterization and Diversity of Rhizobium isolated From Root Nodules of Mid-Altitude Climbing Bean (Phasesolus Vulgaris L.) Varieties". J. Front. Of Microbiol. Vol(9). pp.1-12. 2018 https://doi.org/10.3389/fmicb.2018.00968

41. M. Nahar, Z.Mahal, M. H. Zahid, K. Zaman, F. Jahan, M.M.Rahman, and R. Noor, "Effect of plasmid curing on Rhizobium spp." Stamford J. Microbiol., 2 (1): 34-37.2012. https://doi.org/10.3329/sjm.v2i1.15212

42. K. Bekachew "Intrinsic antibiotic resistance, survival of Rhizobium leguminosarum strains and fixation potential of pea varieties (Pisum satvum L.) In South east Ethiopia” In. J. Mic. Res., 1: 75-79. 2010.

43.A.M.H.I. Al-Zubaidi, "Transfer of plasmids from bacteria S.meliloti to bacteria E.coli by methods of bacterial conjugation and genetic transformation and their role in the formation of root nodes". Master thesis, College of Education, University of Mosul, Iraq. 2005.

44. A. I. S. Pereia, G. I. A Lima,P. A. D. M. E. Figueira "Heavy metal toxicity in Rhizobium leguminosarum biovar viciae isolated from soils subjected to different sources of heavy- metal contamination: Effects on protein expression". 3(33), pp. 286-293. 2006 https://doi.org/10.1016/j.apsoil.2005.10.002

45. W.J.Al-obaidi "Study of the genetic and Plasmid content of Rhizobium sp. Bacterium isolated from the root nodes of some leguminous plants, Amaster' thesis, College of Education , University of Mosul,Iraq.2020.

46. F. Kawaka, H. Makonde, M. Dia, P. Opala, O. Ombori, J. Maingi, J. Muoma "Genetic diversity of symbiotic bacteria modulating common bean (Phasolus vulgaris) in western Kenya" PLoSONE 13(11). 2018. https://doi.org/10.1371/journal.pone.0207403

47. A. Yadav, G. Singh, Kumarrai and M. Singh. "Assessment of Molecular Diversity in Chickpea (Cicer arietinum L.) Rhizobia and Structural Analysis of 16S rDNA Sequences from Mesorhizobium ciceri" Polish J. of Microbio. 3(62), pp. 253-262. 2013. DOI: 10.33073/pjm-2013-033. 